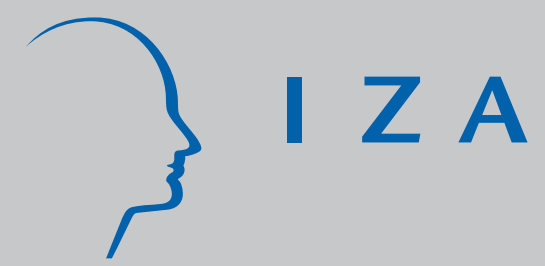

IZA DP No. 9379

Work-Life Balance Practices, Performance-Related Pay, and Gender Equality in the Workplace:

Evidence from Japan

Takao Kato

Naomi Kodama

September 2015

Forschungsinstitut zur Zukunft der Arbeit Institute for the Study of Labor 


\title{
Work-Life Balance Practices, Performance-Related Pay, and Gender Equality in the Workplace: Evidence from Japan
}

\author{
Takao Kato \\ Colgate University, IZA, CJEB, TCER, CCP, and ETLA \\ Naomi Kodama \\ Hitotsubashi University and RIETI \\ Discussion Paper No. 9379 \\ September 2015 \\ IZA \\ P.O. Box 7240 \\ 53072 Bonn \\ Germany \\ Phone: +49-228-3894-0 \\ Fax: +49-228-3894-180 \\ E-mail: iza@iza.org
}

\begin{abstract}
Any opinions expressed here are those of the author(s) and not those of IZA. Research published in this series may include views on policy, but the institute itself takes no institutional policy positions. The IZA research network is committed to the IZA Guiding Principles of Research Integrity.

The Institute for the Study of Labor (IZA) in Bonn is a local and virtual international research center and a place of communication between science, politics and business. IZA is an independent nonprofit organization supported by Deutsche Post Foundation. The center is associated with the University of Bonn and offers a stimulating research environment through its international network, workshops and conferences, data service, project support, research visits and doctoral program. IZA engages in (i) original and internationally competitive research in all fields of labor economics, (ii) development of policy concepts, and (iii) dissemination of research results and concepts to the interested public.
\end{abstract}

IZA Discussion Papers often represent preliminary work and are circulated to encourage discussion. Citation of such a paper should account for its provisional character. A revised version may be available directly from the author. 


\section{ABSTRACT}

\section{Work-Life Balance Practices, Performance-Related Pay, and Gender Equality in the Workplace: Evidence from Japan*}

This paper uses unique firm-level panel data from Japan and provides new evidence on the possible impact on gender equality in the workplace of human resources management (HRM) practices. Specifically we consider a number of work-life balance (WLB) practices that are developed in part to enhance gender equality as well as performance-related pay (PRP) that is one of the most often discussed changes in the Japanese HRM system in recent years. Our fixed effect estimates indicate that daycare service assistance (onsite daycare services and daycare service allowances) has a gradual yet significant positive effect on the share of women in the firm's core labor force and the proportion of female directors. However, transition period part-time work is found to result in a decrease in the proportion of female directors (or exacerbating gender inequality in management). Turning to PRP, the fixed effect estimates suggest that a switch from the traditional wage system that rewards workers for their long-term skill development through on-the-job training within the firm to PRP that makes pay more sensitive to shorter-term performance will result in a fall in the proportion of female directors. We also find that the adverse effect on gender equality of PRP is fully mediated by having a more objective performance evaluation system; a more transparent decision making process; and a more systematic, explicit and formal training program. This finding can be interpreted as evidence pointing to gender discrimination in the workplace. In designing, developing and revising public policy instruments to achieve Prime Minister Shinzo Abe's ambitious policy goal of "increasing the share of women in leadership positions to at least $30 \%$ by 2020 in all fields in society," policy makers may need to pay particular attention to heterogeneous efficacy of specific WLB practices and the adverse effect of PRP as well as the mediating role played by management by objectives (MBO), information sharing, and systematic training program.

JEL Classification: M5, J16

Keywords: $\quad$ work-life balance, performance-related pay, pay for performance, HRM practices, gender equality, gender diversity, Japan

Corresponding author:

Takao Kato

Department of Economics

Colgate University

13 Oak Drive

Hamilton, NY 13346

USA

E-mail: tkato@colgate.edu

\footnotetext{
${ }^{*}$ We are grateful to the participants of the seminar at Research Institute Economy, Trade and Industry (RIETI), the Tokyo Labor Economics Workshop, and the 2015 spring conference of Japanese Economic Association for their helpful discussions on this paper, especially Tsutomu Miyagawa, Kyoji Fukao, Masahisa Fujita, Masayuki Morikawa, Yoko Konishi, Hideo Owan, Nobuko Nagase, Emiko Usui, Daiji Kawaguchi, Yukiko Asai, Akira Wakisaka, and Tsuyoshi Tsuru. This study is conducted as part of the Project "Study on Intangible Assets in Japan" undertaken at Research Institute of Economy, Trade and Industry (RIETI), and this paper is based on the RIETI Discussion Paper Series 15-E-112. All remaining errors are our own and the views expressed in this paper are solely those of the authors and are not necessarily those of the organizations to which we belong.
} 


\section{Work-Life Balance Practices, Performance-Related Pay, and Gender Equality in the Workplace: Evidence from Japan}

\section{$\underline{1 .}$ Introduction}

A large number of studies consider HRM practices as intangible assets and estimate their effect on productivity (for a recent review of the literature, see Bloom and van Reenen, 2011). Yet a relatively fewer studies estimate their effects on gender diversity in the workplace, and hence the impact on gender inequality of HRM practices is not well understood (Castilla, 2012). This paper uses unique firm-level panel data from Japan and provides new evidence on the possible impact on gender equality in organizations of a variety of HRM practices.

The use of Japanese data is of particular interest. In Japan gender gaps in the labor market are considerable. According to the OECD, the gender gap in median earnings for full-time employees in Japan was approximately 29\% in 2012 (or women earn 29\% less than men), almost twice as high as the OECD average. The persistently large gender pay gap in Japan is particularly troublesome for policy makers since gender gaps in educational attainment narrowed considerably in Japan (Abe, 2010). As the proportion of college-educated women has increased, the worker composition of full-time workers has changed dramatically. In particular, there has been a significant increase in the proportion of female university graduates among full-time workers. Further, the average tenure of full-time female workers rose from 6.2 years in 1981 to 8.9 years in 2010 (the Basic Survey on Wage Structure, Japanese Ministry of Health, Labor and Welfare). Despite these improvements in female education and tenure, however, significant gender wage gaps persist in Japan.

Presently Japanese policy makers consider narrowing such gender gaps a top policy priority (see, for instance, Prime Minister Abe's ambitious policy goal of "increasing the share of women in leadership positions to at least $30 \%$ by 2020 in all fields in society"). The current 
policy focus on gender gaps in the labor market is in part motivated by Japan's rapidly aging population and the resultant shrinking labor force and diminishing economic dynamism. Greater labor force participation and career advancement of women are often advocated as the most promising "solution" to Japan's demographic challenge (see, for instance, a recent IMF report “Can Women Save Japan?” by Steinberg and Nakane, 2012).

In addition to the afore-mentioned macroeconomic and demographic needs for further career development of women, a growing body of evidence points to the microeconomic needs for gender diversity in the workplace - gender diversity as a source of corporate competitiveness (see, for instance, Gregory-Smith; Main and O'Reilly, III. 2014 for the U.K., Adams and Ferreira, 2009 for the U.S., Liu, Wei and Xie. 2014 for China, and Smith, Smith and Verner. 2013 for Denmark).

The empirical literature on gender gaps in the labor market in Japan tends to focus on assessing the efficacy of public policy instruments at the macro level such as revisions of Japan's "paternalistic" Labor Standard Law, parental leave legislations, and increasing public daycare facilities (see, for instance, Kato and Kodama, 2014, Asai, 2015, Kato, et al., 2014, Asai, Kambayashi, and Yamaguchi, 2015, Unayama and Yamamoto, 2015, Higuchi, Matsuura, and Sato, 2008, Abe, 2013, and Lee and Lee, 2014). In contrast, there is a paucity of rigorous evidence on the efficacy of HRM policies and practices at the micro (firm) level----especially Work-Life Balance (WLB) practices in Japan. ${ }^{1}$ It is this important gap in the literature that we hope to fill in this paper. ${ }^{2}$

\footnotetext{
${ }^{1}$ Kawaguchi (2013), Wakisaka (2007) and Yanadori and Kato (2009) provide cross-sectional evidence which is subject to bias caused by unobserved firm heterogeneity.

${ }^{2}$ Albeit the paucity of rigorous evidence on the impact on advancement of women in the labor market of WLB practices in Japan, there is a growing body of rigorous evidence in other industrialized nations - for instance, Gupta, Smith and Mette (2008); Bloom, et. al. (2009); Arthur and Cook (2004); Baxter and Chesters (2011); Berg, et.al. (2014); and Bud and Mumford (2004).
} 
A full assessment of the impact on gender equality of HRM practices requires firm-level panel data which provide longitudinal data on the incidence of various HRM practices as well as diverse dimensions of labor market outcome for women as compared to men. To this end, we merge the following three firm-level panel datasets using unique company codes; (i) Data from the Intangible Assets Interview Survey in Japan conducted by the RIETI (Research Institute of Economy, Trade, and Industry); (ii) CSR Data compiled by Toyo Keizai ${ }^{3}$; and (iii) Corporate Proxy Statement Data compiled by Development Bank of Japan.

The merged database consists of 4,697 publicly-traded firms in Japan, and provide annual data for each firm over 2003-2011. Importantly the database provides longitudinal information on the incidence of a variety of WLB practices (e.g., Flextime, Telecommuting, Satellite Office, Transition Period Part-Time Schedule; and Daycare service assistance (e.g., onsite daycare services and daycare service allowances for those who use other daycare services).

In addition to WLB practices, our database also provides panel data on the incidence of high-performance work practices (HPWPs). One of the most often-discussed changes in HPWPs in Japan over the last two decades is the adoption of Performance-Related Pay, PRP (see, for instance, Tatsumichi and Morishima, 2007). Following the burst of the financial bubble at the end of the 1980s, the Japanese economy fell into prolonged stagnation (Japan's Great Recession or Lost Decade). The inability of the Japanese employment system to respond to rapidly changing market conditions during Japan's Great Recession was often accused of a structural impediment to the swift and robust recovery of the Japanese economy (Ono and Rebick, 2003). Influential associations of Japanese business leaders, such as Keizai Doyukai (Japan Association of Corporate Executives) and Nippon Keidanren (Japan Business Federation) called for a replacement of the Japanese system with the U.S. system. In this context, interest in American-

\footnotetext{
${ }^{3}$ The data was provided by the RIETI.
} 
style individual incentive pay--Performance-Related Pay (PRP) rose. While the traditional Japanese pay system tends to reward long-term skill acquisition through on-the-job training within the firm, American-style PRP makes pay more sensitive to relatively short-term performance. ${ }^{4}$ For instance, under American-style PRP, individual worker pay is determined by the supervisor's annual assessment of the extent to which the worker achieves a set of specific goals that were set during the annual consultation at the beginning of the year. A switch from the traditional Japanese pay system to the American-style PRP has been recommended as a means to boost Japanese firms' productivity and maintain/regain their competitiveness.

Naturally the literature tends to focus on the efficacy of PRP as a performance-enhancing instrument (see for instance Benson and Brown, 2000, and Kato and Kodama, 2015), and no attempt has been made to conduct a rigorous econometric study of the possible effect on gender equality in the workplace of Japanese PRP. This paper provides novel evidence on the consequences of PRP for gender inequality in Japan. ${ }^{5}$

Popular writings tend to portray a switch from the traditional wage system to PRP as a blessing for those who believe in womenomics - advancement of women in the labor market as a solution to Japan's demographic challenge. There are, however, reasons to believe that the opposite may be the case - the introduction of PRP results in an increase in gender inequality in the workplace. First, the traditional Japanese pay system tends to stress the importance of the worker's long-term skill acquisition through experiencing a variety of jobs within the firm as a

\footnotetext{
${ }^{4}$ The English-language literature on recent changes in the Japanese pay system is thin. A notable recent exception is Chiang and Ohtake (2014). For the Japanese-language literature, see, for instance, Tsuru, Abe, and Kubo (2005).

${ }^{5}$ Most recently Chiang and Ohtake (2014) study the possible effect on the structure of gender wage gaps of PRPs in Japan. Our study differs from Chiang and Ohtake (2014) in at least two important ways. First, instead of focusing on pay, we investigate gender gaps in employment and promotion in the workplace. Second, unlike their study that uses cross-section data and hence does not use fixed effect models, the panel nature of our data allow us to use fixed effect models and account for unobserved firm heterogeneity. As such we believe our study complements Chiang and Ohtake (2014).
} 
key determinant of pay. Since such internal human capital accumulation increases with tenure, under the traditional Japanese pay system, pay rises with tenure. A shift from such a "seniority" pay system to PRP may create more (rather than less) room for gender discrimination. After all, performance is in principle more subjective than tenure as a criterion for pay raise and promotion. Second, recent research in behavioral economics provide evidence that women shy away from competition while men embrace it (Niederle and Vesterlund, 2006). A shift toward PRP can be considered a workplace climate shift toward more intense competition. As such, the introduction of PRP may well result in diminished career advancement of women. We further explore possible interplay between PRP and other practices that are often considered an integral part of the Japanese high-performance work system (Kato and Morishima, 2002).

Our data are rich in labor market outcome measures. As such, we are able to gauge the degree of gender equality in the workplace at the different levels from the level of female employment to the proportion of female directors.

Our preferred empirical strategy, fixed effect model estimation, yields mixed evidence on the efficacy of WLB practices as means to reduce gender inequality. On the one hand, daycare service assistance is found to have a gradual yet significant positive effect on gender equality in general as well as gender equality at the higher (management) levels. On the other hand, we find that "temporary" transition period part-time work arrangement will result in a decrease in the proportion of female directors (or increased gender inequality in management).

Turning to PRP, we find evidence that a switch from the traditional Japanese pay system to PRP will result in a decrease in the proportion of female directors (amplifying gender inequality in management). The inequality-enhancing effect of PRP has two interpretations: (i) a switch from the traditional wage system to PRP creates more room for gender discrimination; 
and (ii) PRP changes the workplace climate toward more intense competition, and women shy away from competition while men embrace it. We find some indirect evidence that the adverse effect on gender equality of PRP is mediated fully by having a more objective performance evaluation system, a more transparent decision making process and a more systematic, explicit and formal training program. As such, our findings suggest that gender discrimination may play a significant role in exacerbating gender inequality under PRP.

In the next section we study the effect on gender equality in the workplace of WLB Practices. Section III turns to PRP and its effect on gender equality. Section IV concludes.

\section{Gender equality in the workplace and WLB Practices}

To investigate empirically the efficacy of WLB practices as means to reduce gender inequality in the workplace, we estimate the following fixed effect models:

$$
\begin{aligned}
& \text { GenderEquality }_{i t}=\alpha+\beta_{11} \text { Flex }_{i t}++\beta_{12} \text { FlexAge }_{i t}+\beta_{21} \text { Rhours }_{i t}+\beta_{22} \text { RhoursAge }_{i t} \\
& \quad+\beta_{31} \text { Daycare }_{i t}++\beta_{32} \text { DaycareAge }_{i t}+X_{i t}+(\text { firm fixed effects })+(\text { year effects })+\varepsilon_{\text {it }}
\end{aligned}
$$

To gauge the degree of gender equality in the workplace (GenderEqualityit), we consider the following three variables: (i) Fmanagerit $=$ the number of female managers of firm $i$ in year $t$; (ii) Fdirectorit $=$ the number of female directors (typically called "bucho" in the Japanese workplace) of firm $\mathrm{i}$ in year $\mathrm{t}$; and (iii) Femployee ${ }_{i t}=$ the number of female standard employees of firm $\mathrm{i}$ in year $\mathrm{t}$.

For Work-Life Balance polices, our data allow us to consider three categories of WLB practices: (i) Flexit $=1$ if firm $i$ in year $t$ uses at least one of the following three flexible scheduling policies/programs: (a) flextime; (b) telecommuting; and (c) satellite office, 0 otherwise; (ii) Rhoursit $=1$ if firm $\mathrm{i}$ in year $\mathrm{t}$ allows its employees to take a temporary transitional 
part-time work (e.g., female employees return to work after maternity leave as a temporary transitional part-time worker for a fixed period of time), 0 otherwise; and (iii) Daycare $_{i t}=1$ if firm i has a company daycare center (including a reimbursement program for those who use public daycare centers) in year t, 0 otherwise. Since it is highly unlikely that HRM practices such as WLB polices have immediate impact on gender inequality in the workplace, we consider oneyear lag. Furthermore, HRM practices are shown to evolve in their scope, nature and effects over time (see, for instance, Kato, 2006, and Müller and Stegmaier, 2014). To capture such dynamic effects, we add the age of each category of WLB practices.

It is plausible that the use of WLB practices is correlated with unobserved firm characteristics that tend to be time-invariant, such as corporate culture, tradition and underlying managerial quality. Furthermore, such unobserved firm characteristics are likely to be correlated with gender equality in the workplace. Without accounting for such unobserved firm heterogeneity, the estimated coefficients will be biased. Fortunately our data are longitudinal, and thereby allow us to estimate firm fixed effect models and hence account for such unobserved firm heterogeneity.

To control for common year effects (including common trends and macro shocks), we will also consider year fixed effects. Finally, we also control for time-variant firm characteristics such as employment (in log), proportion of foreign capital, and ROA. ${ }^{6}$

We form our prior expectations on the direction of the effect of each of the three categories of WLB practices, in part based on our recent field research at two large manufacturing firms in Japan (both firms are listed in the first section of Tokyo Stock Exchange and produce globally well-known products). Our informants at both cases (who are managers in

\footnotetext{
${ }^{6}$ Our key results are found to be robust to alternative sets of time-variant firm characteristics, such as profit margin instead of ROA.
} 
charge of WLB) stress the efficacy of their onsite daycare centers. At one firm, they were able to give us two specific examples in which female employees were able to become managers in part thanks to the availability of their convenient onsite daycare center. However, our informants at both case firms also emphasize the negative effect on work quality and eventually career advancement of women of the temporary and transitional part-time work arrangement. Female employees returning from their parental leave who use the program are often unable to maintain the quality of their work, which harm their chance of career advancement. In fact, though the program is supposed to be a temporary and transitional part-time arrangement, some women end up using the program well beyond the "transitional" period and diminishing their chance of career advancement significantly. Our informants told us that they had been trying to talk to promising female employees about the potentially adverse impact on career advancement of using the program, and dissuade them to use it, but only with limited success. Thus, we expect the temporary and transitional part-time work program to be ineffective and possibly have even a negative effect on gender equality at the higher (management) levels.

Table 1 shows summary statistics, and all fixed effect estimates are reported in Table 2. As shown in Table 2, our fixed-effect estimates yield mixed evidence on the efficacy of WLB practices as means to reduce gender inequality. Perhaps most encouraging results are found for daycare services. First, the estimated coefficient on Daycare it is positive and statistically significant at the 10 percent level when we use the number of female standard employees as the dependent variable. The size of the estimated coefficient suggests that having a company daycare center and/or a daycare expense reimbursement policy will lead to 40 more female standard employees, which amounts to close to 10 percent increase from its mean value of 428 (see Table 1). Note that we are controlling for the total number of standard employees, and therefore the 
proportion of female standard employees will also rise when the firm uses a daycare service program. In addition, the estimated coefficient on the age of the daycare service program, DaycareAge $_{i t}$ is positive and statistically significant at the 1 percent level, pointing to the positive age effect of the program--as the program matures, the positive effect on gender equality of the daycare service program will increase. The magnitude of the coefficient suggests that an additional 17 more female standard employees will be added every year as the program ages. Since the average age of the program is still low, we ought not to extrapolate this too far.

Second, the estimated coefficients on Daycare $i t$ for the other two gender equality measures (gender equality at the higher levels) are, however, not statistically significant, suggesting that the daycare program will have no discrete impact on gender equality at the higher levels, even after we wait for one full year. Nevertheless, the estimated coefficients on the age of the daycare program are found to be positive and statistically significant at the 1 percent level, pointing to the significant age effect--the program will have a gradual positive effect on gender equality at the higher levels. The magnitude of the age effect is neither trivial nor implausibleafter the program reaches the age of 1 (DaycareAge $\mathrm{it}_{\mathrm{i}}=1$ ), an additional year of maturing of the program will lead to an increase in the number of female directors by 0.6 and an increase in the number of managers by four. Again, the extrapolation of the result ought to be done with much caution in light of the relatively young age of the program.

The estimated coefficients on the flexible scheduling programs, Flexit and FlexAge it $_{\text {are }}$ not statistically significant except for Fdirector ${ }_{i t}$ as the dependent variable, failing to provide compelling evidence on the significant effect on gender equality at a higher level of a flexible scheduling program.

Turning to the temporary and transitional part-time work program, we find some negative 
effect on gender equality at the higher levels. Specifically the estimated coefficients on Rhoursit are negative when we use the gender equality measures at the higher (managerial) levels, and statistically significant at the 5 percent level for Fdirectorit, confirming our prior expectation based on the field research - the negative effect on work quality of the program and hence career advancement of women. The magnitude of the estimated coefficient indicates that having the program will lead to a decrease in the number of female directors by 0.25 , which is not trivial, considering that the average number of female directors is one. Note that the estimated coefficient on the age of the program is positive and statistically significant at the 5 percent level, pointing to the dissipation of the negative effect on gender equality at the director level of the program over time (again, considering the relatively short panel and the young age of the program, extrapolating the estimates far out-years is not advisable.

\section{Gender equality and Performance-Related Pay (PRP)}

To investigate the possible effect on gender equality in the workplace of PRP, we augment Eq. (1) with the PRP variables:

$$
\begin{aligned}
& \text { GenderEquality }_{i t}=\alpha+\gamma_{11} \text { PRP }_{i t}+\gamma_{12} \text { PRPAge }_{i t} \\
& +\beta_{11} \text { Flexit }+\beta_{12} \text { FlexAge }_{i t}+\beta_{21} \text { Rhoursit }+\beta_{22} \text { RhoursAge }_{i t}+\beta_{31} \text { Daycare }_{i t} \\
& \quad+\beta_{32} \text { DaycareAge }_{i t}+\mathrm{X}_{\mathrm{it}}+(\text { firm fixed effects })+(\text { year effects })+\varepsilon_{i t}
\end{aligned}
$$

where PRP ${ }_{i t}=1$ if firm $\mathrm{i}$ uses PRP in year $\mathrm{t}$, zero otherwise, and PRPAge ${ }_{i t}$ is the age of the PRP scheme in year t. As discussed earlier, the popular narrative notwithstanding, we expect PRP to have negative effects on gender equality in the workplace in general and at the higher levels in particular. 
The fixed effect estimates of Eq. (2) are reported in Table 3. As expected, the estimated coefficients on $\mathrm{PRP}_{i t}$ are negative for all three measures of gender equality and statistically significant at the 5 percent level for gender equality at the director level, Fdirectorit. The size of the coefficient suggests that the adverse effect on gender equality of PRP is rather substantial—a drop in the number of female directors, conditional on the total number of directors, by 0.4 (at the mean number of female directors a little over 1). Note that there is one statistically significant (at the 10 percent level) positive coefficient on the age of PRP for the total number of female standard employees (gender equality measure at all levels). PRP may lead to a gradual and modest increase in the stock of female standard employees after one year of the gestation period (an additional thirteen female standard employees at the mean level of female standard employment is 428). Again, considering the short panel and the young program of PRP, we should not extrapolate far out-years.

Some of our WLB results in the previous section are found to be robust to the augmentation of our baseline model of Eq. (1) with the PRP variables, while some are not. The positive effects on gender equality at the higher levels of the age of the daycare program prove to be largely robust to the augmentation with PRP (remaining statistically significant at the 5 percent level for Fdirectorit and close to being statistically significant for Fmanagerit, while no longer statistically significant for Femployeesit). The negative and significant effect on gender equality at the director level of the temporary and transitional part-time work arrangement is found to be not robust to the augmentation.

Does the negative effect on gender equality at the higher levels of PRP have more to do with the supply side (competition aversion by women) or the demand side (gender discrimination in performance evaluation)? To shed some light on the mechanisms behind the adverse effect on 
gender equality in the workplace of PRP, we augment Eq. (2) further with an interaction term involving $\mathrm{PRP}_{i t}$ and $\mathrm{MBO}_{\mathrm{i}}=1$ if firm $\mathrm{i}$ uses MBO (Management by Objective) and an established evaluation procedure, 0 otherwise. ${ }^{7}$ If the adverse effect on gender equality of PRP has much to do with gender discrimination due to the subjective nature of PRP as compared to the traditional wage system with particular emphasis on tenure, we expect that such negative effect on gender equality of PRP is mediated by the use of MBO (which is aimed at reducing the subjectivity of PRP). In other words, the estimated coefficients on the interaction term, $\mathrm{PRP}_{\mathrm{it}}{ }^{*} \mathrm{MBO}_{\mathrm{i}}$ are positive. Note that we are interested in whether the observed negative effect on gender equality at the higher levels of PRP is mediated by the use of MBO, and therefore that the interaction term $\mathrm{PRP}_{\mathrm{it}}{ }^{*} \mathrm{MBO}_{\mathrm{i}}$ is our main focus. However, to rule out any possibility that the interaction term, $\mathrm{PRP}_{\mathrm{it}}{ }^{*} \mathrm{MBO}_{\mathrm{i}}$ is picking up another interactive effect of the age of PRP and MBO, we also include another interaction term, PRPAge ${ }_{i t}{ }^{*} \mathrm{MBO}_{\mathrm{i}}$.

Table 4 shows the fixed effect estimates of the aforementioned augmented version of Eq. (2). The estimated coefficients on the interaction term are found to be positive for all three gender equality measures, and statistically significant at the 5 percent level for Fdirectorit. In contrast, the estimated coefficient on PRP $\mathrm{P}_{\text {it }}$ is negative and statistically significant at the 5 percent level, pointing to a sizable and significant negative effect on gender equality at the director level of PRP for firms without MBO (a decrease in one female director, following the switch from the traditional wage system to PRP). Most importantly, the magnitude of the estimated coefficient of the interaction term is similar to that of the estimated coefficient on PRP $\mathrm{it}_{\mathrm{i}}$, suggesting that the use of MBO will eliminate the negative effect on gender equality at the director level of PRP

\footnotetext{
${ }^{7}$ For MBO, the data are available only cross-sectionally. As such, we cannot estimate the coefficient on MBO itself in fixed effect models. However, the coefficient on the interaction term involving MBO and PRP can be estimated since PRP is time-variant.
} 
entirely. As such, the evidence is largely consistent with the notion that the negative impact on gender equality of PRP may have something to do with the demand side (gender discrimination).

Likewise, we expect that the adverse effect on gender equality of PRP will be mediated by transparent management with open and frequent information sharing between labor and management. Table 5 summarizes the fixed effect estimates of Eq. (2) augmented by $\mathrm{PRP}_{\mathrm{it}}{ }^{*} \mathrm{INF}_{\mathrm{i}}$ where $\mathrm{INF}_{\mathrm{i}}=1$ if firm i practices transparent management with open and frequent information sharing between labor and management, 0 otherwise. The estimated coefficients on the interaction term are again positive for all three gender equality measures, and statistically significant at the 5 percent level for Femployee it and almost significant at the 10 percent level for Fmanagerit. In contrast, the estimated coefficients on PRP it itself are negative and statistically significant (at the 1 percent level for Fdirectorit, at the 10 percent level for Fmanagerit, and at the 5 percent level for Femployee ${ }_{i t}$ ). It follows that for firms that lack transparent management with open and frequent information sharing, PRP will lead to a decrease in gender equality in the workplace (a drop in the number of female director by 0.6 ; a fall in the number of female managers by 5 ; and a decrease in the stock of female standard employment by 45 ). Comparing the size of the estimated coefficients on the interaction term with the size of the estimated coefficient on PRP itself reveals that the use of transparent management will mediate the adverse impact on gender equality of PRP fully. As such, there is again some indication for gender discrimination as a possible culprit for the adverse consequence of a switch from the traditional wage system to PRP for gender equality in the workplace.

Lastly, a systematic and well-established explicit training program as opposed to informal on-the-job training (e.g., informal and personal mentoring by senior workers through social network) may help alleviate the adverse effect on gender equality of PRP. To this end, we 
construct TRAIN $\mathrm{i}_{\mathrm{i}}=1$ if firm $\mathrm{i}$ uses a systematic and well-established training program (including both OJT and OffJT), 0 otherwise, and augment Eq. (2) with PRP $_{i t}$ *TRAIN ${ }_{i}$. The fixed effect estimates are presented in Table 6 . To confirm our prior expectation, the estimated coefficients on the interaction term are positive for all three gender equality measures although they are not quite precisely estimated (the estimated coefficient for Fmanager ${ }_{i t}$ as the dependent variable is close to being significant at the 10 percent level). The estimated coefficients on $\mathrm{PRP}_{\text {it }}$ per se are negative for all three gender equality variables and statistically significant at the 10 percent level for Fdirectorit and at the 5 percent level for Fmanager $i$, and close to being significant at the 10 percent level for Femployee ${ }_{i t}$. Without a systematic, explicit and well-established training program, PRP is found to result in a fall in the number of female directors by 0.4 ; a drop in the number of female managers by 3 ; and a reduction in the level of female standard employment by 12 . Though not as strongly as MBO and INF, the results on TRAIN are also consistent with the notion that the adverse impact on gender equality of PRP may have something to do with gender discrimination in informal training in the workplace (for instance, in the workplace in which training is often conducted informally, male workers are more likely to receive relevant training informally from their male supervisors through "old boys network," while female workers have less opportunity to benefit from such informal training) 


\section{Concluding remarks}

This paper has provided new evidence on the possible effect on gender equality in organizations of a variety of HRM practices. We have considered two types of HRM practices: (i) Work-Life Balance (WLB) practices that are often considered helpful for career development of women; and (ii) Performance-Related Pay, PRP that are not well understood in terms of their impact on gender inequality in the workplace (Castilla, 2012). To account for unobserved firm heterogeneity such as corporate culture, tradition and underlying managerial quality, and gauge gender inequality in diverse dimensions, we have assembled unique panel data over 2003-2011 by merging a number of firm-level panel datasets in Japan. The use of Japanese data is of particular interest, for in Japan gender gaps in the labor market are considerable and persistent in spite that gender gaps in educational attainment narrowed significantly over the last three decades. Reducing gender inequality in the workplace is a top public policy priority for Japanese policy makers.

Our fixed effect estimates have yield mixed evidence on the efficacy of WLB practices as means to reduce gender inequality in the workplace. On the one hand, daycare service assistance has been found to have a gradual yet significant positive effect on gender equality in general as well as gender equality at the higher (management) levels. On the other hand, we have found that transition period part-time work arrangement will result in a decrease in the proportion of female directors (or increased gender inequality in management).

Turning to PRP, we have found evidence that the introduction of PRP will result in a decrease in the proportion of female directors (amplifying gender inequality in management). The inequality-enhancing effect of PRP has two interpretations: (i) a switch from the traditional wage system with emphasis on seniority to PRP creates more room for gender discrimination; 
and (ii) PRP changes the workplace climate from cooperation to competition and women shy away from competition while men embrace it (such a competition-inducing effect of PRP may take the form of intensified rat race with excessively long working hours for promotion tournament which deters women from competing for promotion).

We have found some evidence that the adverse effect on gender equality of PRP is mediated fully by having a more objective performance evaluation system, a more transparent decision making process and a more systematic, explicit and formal training program, suggesting that gender discrimination may play a significant role in exacerbating gender inequality under PRP.

Presently policy makers are encouraging Japanese firms to further their shift of the traditional pay system to PRP. For instance, the government recently adopted a bill to revise Japan's Labor Standard Law, which will allow employers to exempt their employees (excluding low-wage employees) from overtime regulations, and pay them according to their performance. Our findings suggest that such a shift toward PRP may exacerbate gender inequality in the workplace unless mediating practices such as a more transparent and objective performance evaluation system, a more transparent and sharing decision making process with open and more frequent information sharing, and a more systematic, explicit and formal training program accompany such a shift. ${ }^{8}$

In addition, among WLB practices, our evidence points to the efficacy of daycare service assistance as an instrument to enhance gender equality in the workplace as well as the opposite equality-diminishing effect of transition period part-time schedule. In designing, developing, and revising public policy instruments to achieve Prime Minister Abe's ambitious policy goal of

\footnotetext{
${ }^{8}$ Unlike typical PRP scheme, the PRP scheme proposed in the bill allows employees to opt out of the scheme. It is possible that such voluntary nature of the proposed PRP may make its effects differ from those we identified in this paper. As such, our policy implications ought not to be considered definitive.
} 
"increasing the share of women in leadership positions to at least $30 \%$ by 2020 in all fields in society", policy makers may need to pay particular attention to heterogeneous efficacy of specific WLB practices and the adverse effect of PRP as well as the mediating role played by MBO, information sharing, and systematic training program. 
References

Abe, Yukiko. 2010. "Equal Employment Opportunity Law and the Gender Wage Gap in Japan: A Cohort Analysis." Journal of Asian Economics, Vol. 21, No. 2, pp. 142-155.

Abe, Yukiko. 2013. "Regional Variations in Labor Force Behavior of Women in Japan." Japan and the World Economy, Vol. 28, No., pp. 112-124.

Adams, Renee B. and Daniel Ferreira. 2009. "Women in the Boardroom and Their Impact on Governance and Performance." Journal of Financial Economics, Vol. 94, No. 2, pp. 291309.

Arthur, Michelle M. and Alison Cook. 2004. "Taking Stock of Work-Family Initiatives: How Announcements of 'Family-Friendly' Human Resource Decisions Affect Shareholder Value." Industrial and Labor Relations Review, Vol. 57, No. 4, pp. 599-613.

Asai, Yukiko. 2015. "Parental Leave Reforms and the Employment of New Mothers: QuasiExperimental Evidence from Japan." Labour Economics (forthcoming), Vol., No.

Asai, Yukiko, Ryo Kambayashi and Shintaro Yamaguchi. 2015. "Childcare Availability, Household Structure, and Maternal Employment." Journal of the Japanese and International Economies (forthcoming), Vol., No.

Benson, John and Michelle Brown. 2000. "Individual Performance Related Pay and Enterprise Outcomes in Australia and Japan". International Employment Relations Association (University of Technology, Sydney). 8: 1-26.

Berg, Peter, Ellen Ernst Kossek, Kaumudi Misra and Dale Belman. 2014. "Work-Life Flexibility Policies: Do Unions Affect Employee Access and Use?" Industrial and Labor Relations Review, Vol. 67, No. 1, pp. 111-137.

Bloom, Nicholas and John Van Reenen. 2011. Human Resource Management and Productivity. In Orley Ashenfelter and David Card. Handbook of Labor Economics, pp 1697 - 1767: Elsevier.

Bloom, Nick, Tobias Kretschmer, John Van Reenen, Richard B. Freeman and Kathryn L. Shaw. 2009. Work-Life Balance, Management Practices, and Productivity. In., International Differences in the Business Practices and Productivity of Firms, pp 15-54: A National Bureau of Economic Research Conference Report. Chicago and London: University of Chicago Press.

Budd, John W. and Karen Mumford. 2004. "Trade Unions and Family-Friendly Policies in Britain." Industrial and Labor Relations Review, Vol. 57, No. 2, pp. 204-222.

Castilla, Emilio J. 2012. "Gender, Race, and the New (Merit-Based) Employment Relationship." Industrial Relations, Vol. 51, No., pp. 528-562.

Chiang, Hui-Yu and Fumio Ohtake. 2014. "Performance-Pay and the Gender Wage Gap in Japan". 34: 71-88.

Gregory-Smith, Ian, Brian G. M. Main and Charles A. O'Reilly, III. 2014. "Appointments, Pay and Performance in Uk Boardrooms by Gender." Economic Journal, Vol. 124, No. 574, pp. F109-28.

HIGUCHI, Y., T. MATSUURA and K. SATO. 2007. "Effects of Regional Factors on Fertility and Employment Continuity of Wives". RIETI Discussoin Paper No. 07-J-012 (in Japanese).

Kato, Takao. 2006. "Determinants of the Extent of Participatory Employment Practices: Evidence from Japan." Industrial Relations, Vol. 45, No. 4, pp. 579-605.

Kato, Takao , Daiji Kawaguchi, Hiromasa Ogawa and Hideo Owan. 2014. "Working Hours, Promotion and the Gender Gaps in the Workplace: Theory and Evidence from an 
Econometric Case Study". Sydney, Australia.

Kato, Takao and Naomi Kodama. 2014. "Labor Market Deregulation and Female Employment:

Evidence from a Natural Experiment in Japan". IZA Discussion Paper No. 8189.

Kato, Takao and Naomi Kodama. 2015. "Performance-Related Pay and Productivity: Evidence from Japan". RIETI Discussion Paper 15-E-088.

Kato, Takao and Motohiro Morishima. 2002. "The Productivity Effects of Participatory

Employment Practices: Evidence from New Japanese Panel Data." Industrial Relations, Vol. 41, No. 4, pp. 487-520.

Kawaguchi, Akira. 2013. "Equal Employment Opportunity Act and Work-Life Balance: Do

Work-Family Balance Policies Contribute to Achieving Gender Equality?" Japan Labor

Review, Vol. 10, No. 2, pp. 35-56.

Lee, Grace H. Y. and Sing Ping Lee. 2014. "Childcare Availability, Fertility and Female Labor

Force Participation in Japan." Journal of the Japanese and International Economies, Vol. 32, No., pp. 71-85.

Liu, Yu, Zuobao Wei and Feixue Xie. 2014. "Do Women Directors Improve Firm Performance in China?" Journal of Corporate Finance, Vol. 28, No., pp. 169-184.

Müller, Steffen and Jens Stegmaier. 2014. "The Dynamic Effects of Works Councils on Labor Productivity: First Evidence from Panel Data". LASER Discussion Papers - Paper No. 78.

Niederle, Muriel and Lise Vesterlund. 2007. "Do Women Shy Away from Competition? Do Men Compete Too Much?" Quarterly Journal of Economics, Vol. 122, No. 3, pp. 1067-1101.

Ono, Hiroshi and Marcus E. Rebick. 2003. Constraints on the Level and Efficient Use of Labor. In Magnus Blomstrom, Jennifer Corbett, Fumio Hayashi and Anil Kashyap. Structural Impediments to Growth in Japan, pp 225-257. Chicago and London: NBER Conference Report series. University of Chicago Press.

Smith, Nina, Valdemar Smith and Mette Verner. 2013. "Why Are So Few Females Promoted into Ceo and Vice President Positions? Danish Empirical Evidence, 1997-2007." Industrial and Labor Relations Review, Vol. 66, No. 2, pp. 380-408.

Steinberg, Chad and Masato Nakane. 2012. "Can Women Save Japan?". IMF Working Paper $\mathrm{WP} / 12 / 248$.

Tatsumichi, Shingo and Motohiro Morishima. 2007. "Seikashugi from an Employee Perspective." Japan Labor Review, Vol. 4, No. 2, pp. 79-104.

Tsuru, Tsuyoshi, Masahiro Abe and Katsuyuki Kubo. 2005. Nihon Kigyo No Jinji Kaikaku (Personnel Reform in Japanese Firms). Tokyo: Oriental Economist.

Unayama, Takashi, and Manabu Yamamoto. 2015. "The impact of the capacity of nursery schools on female labor participation ratio and total fertility rate." Policy Research Institute, Ministry of Finance, Discussion Paper Series 15A-2.

Wakisaka, Akira. 2007. "Implementation and Status of Work-Life Balance Viewed from Matching Data." Japan Labor Review, Vol. 4, No. 4, pp. 7-35.

Yanadori, Yoshio and Takao Kato. 2009. "Work and Family Practices in Japanese Firms: Their Scope, Nature and Impact on Employee Turnover". Routledge. 20: 439-456. 
Table 1 Summary Statistics

\begin{tabular}{|c|c|c|c|c|}
\hline Variable & Definition & Obs & Mean & Std. Dev. \\
\hline Fdirector $_{i t}$ & $\#$ of female directors in firm $\mathrm{i}$ in year $\mathrm{t}$ & 5447 & 1.23 & 5.59 \\
\hline Fmanager $_{\text {it }}$ & $\#$ of female managers in firm $i$ in year $t$ & 5607 & 18.69 & 96.72 \\
\hline Femployee $_{i t}$ & \# of female standard employees in firm $\mathrm{i}$ in year $\mathrm{t}$ & 5418 & 427.86 & 931.79 \\
\hline Flex $_{\text {it }}$ & $=1$ if firm $\mathrm{i}$ has a flexible scheduling practice in year $\mathrm{t}, 0$ otherwise & 5607 & 0.58 & 0.49 \\
\hline FlexAge $_{i t}$ & The age of firm i's flexible scheduling practice in year $t$ & 5607 & 1.91 & 2.51 \\
\hline Rhours $_{\text {it }}$ & $=1$ if firm i has a temporary transitional part-time work program in year $\mathrm{t}, 0$ otherwise & 5595 & 0.75 & 0.43 \\
\hline RhoursAge $_{\text {it }}$ & The age of firm i's temporary transitional part-time work in year $t$ & 5602 & 2.22 & 2.46 \\
\hline Daycare $_{\mathrm{it}}$ & $\begin{array}{l}=1 \text { if firm i has a company daycare center (including a reimbursement program for those } \\
\text { who use public daycare centers) in year } t, 0 \text { otherwise }\end{array}$ & 5454 & 0.16 & 0.37 \\
\hline DaycareAge $_{\text {it }}$ & The age of firm i's daycare program in year $t$ & 5494 & 0.46 & 1.42 \\
\hline $\mathrm{PRP}_{\mathrm{it}}$ & $=1$ if firm $i$ has PRP in year $t, 0$ otherwise & 889 & 0.68 & 0.47 \\
\hline PRPAge $_{i t}$ & The age of firm i's PRP program in year $t$ & 659 & 10.43 & 10.77 \\
\hline $\mathrm{MBO}_{\mathrm{i}}$ & $=1$ if firm i uses Management by Objective, 0 otherwise & 922 & 0.48 & 0.50 \\
\hline $\mathrm{INF}_{\mathrm{i}}$ & $\begin{array}{l}=1 \text { if firm i practices transparent management with open and frequent information } \\
\text { sharing between labor and management, } 0 \text { otherwise }\end{array}$ & 811 & 0.47 & 0.50 \\
\hline TRAIN $_{\mathrm{i}}$ & $\begin{array}{l}=1 \text { if firm } \mathrm{i} \text { uses a systematic and well-established training program (including both } \\
\text { OJT and OffJT), } 0 \text { otherwise. }\end{array}$ & 920 & 0.23 & 0.42 \\
\hline Labor $_{\text {it }}$ & \# of standard employees of firm $\mathrm{i}$ in year $\mathrm{t}$ & 5607 & 2644 & 5647 \\
\hline Pforeigncap $_{\text {it }}$ & Proportion of foreign capital of firm $\mathrm{i}$ in year $\mathrm{t}$ & 5401 & 0.13 & 0.13 \\
\hline $\mathrm{ROA}_{\text {it }}$ & ROA of firm $i$ in year $t$ & 5607 & 0.05 & 0.06 \\
\hline Director $_{\text {it }}$ & $\#$ of all directors of firm $\mathrm{i}$ in year $\mathrm{t}$ & 5447 & 119 & 269 \\
\hline Manager $_{\text {it }}$ & $\#$ of all managers of firm $i$ in year $t$ & 5607 & 664 & 1612 \\
\hline
\end{tabular}

Data: the Intangible Assets Interview Survey in Japan conducted by the RIETI; CSR Data compiled by Toyo Keizai; Yakuin Shikiho (Compnay Officer Listing) compiled by Toyo Keizai; and Corporate Proxy Statement Data compiled by Development Bank of Japan. 
Table 2 Fixed Effect Estimates on the Effect on Gender Equality of WLB Practices

Dependent variable $=$

\begin{tabular}{|c|c|c|c|}
\hline & Fdirector $_{\text {it }}$ & Fmanager $_{\text {it }}$ & Femployee $_{i}$ \\
\hline \multirow[t]{2}{*}{ Flex $_{i t}$} & $0.371^{*}$ & -3.533 & -13.693 \\
\hline & [1.664] & {$[-0.576]$} & {$[-0.457]$} \\
\hline \multirow[t]{2}{*}{ FlexAge $_{i t}$} & 0.021 & -1.600 & -4.570 \\
\hline & [0.493] & {$[-0.734]$} & {$[-0.569]$} \\
\hline \multirow[t]{2}{*}{ Rhours $_{\text {it }}$} & $-0.250 * *$ & -2.313 & 5.796 \\
\hline & [-1.983] & {$[-1.068]$} & {$[0.152]$} \\
\hline \multirow[t]{2}{*}{ RhoursAge $_{\text {it }}$} & $0.086^{* *}$ & -3.487 & 1.516 \\
\hline & [2.136] & {$[-0.918]$} & {$[0.223]$} \\
\hline \multirow[t]{2}{*}{ Daycare $_{i t}$} & -0.130 & -2.431 & $40.606^{*}$ \\
\hline & {$[-0.410]$} & {$[-0.490]$} & {$[1.736]$} \\
\hline \multirow[t]{2}{*}{ DaycareAge $_{i t}$} & $0.589 * * *$ & $4.209^{* * *}$ & $16.656^{* * *}$ \\
\hline & [3.939] & [3.054] & {$[2.605]$} \\
\hline \multirow[t]{2}{*}{ Labor $_{i t}$} & 0.000 & 0.010 & $0.089^{* *}$ \\
\hline & {$[-0.460]$} & [1.362] & {$[2.170]$} \\
\hline \multirow[t]{2}{*}{ Pforeigncap $_{\text {it }}$} & 0.174 & 12.456 & 63.501 \\
\hline & [0.140] & {$[0.832]$} & {$[0.551]$} \\
\hline \multirow[t]{2}{*}{$\mathrm{ROA}_{\mathrm{it}}$} & 0.331 & -2.643 & -65.787 \\
\hline & {$[0.500]$} & {$[-0.312]$} & {$[-0.824]$} \\
\hline \multirow[t]{2}{*}{ Director $_{i t}$} & $0.014 * * *$ & & \\
\hline & [3.806] & & \\
\hline \multirow[t]{2}{*}{ Manager $_{i t}$} & & $0.036^{* *}$ & \\
\hline & & [2.036] & \\
\hline $\mathrm{R}^{2}$ & 0.265 & 0.130 & 0.034 \\
\hline $\mathrm{N}$ & 5114 & 5255 & 5952 \\
\hline
\end{tabular}

Data: the Intangible Assets Interview Survey in Japan conducted by the RIETI; CSR Data compiled by Toyo Keizai; and Corporate Proxy Statement Data compiled by Development Bank of Japan.

Notes: All models include firm-fixed effects and time effects. Absolute values of $t$ statistics based on cluster-robust standard errors are in parentheses.

Significance level: $* * * 1$ percent $* * 5$ percent $* 10$ percent 
Table 3 Fixed Effect Estimates on the Effect on Gender Equality of PRP

Dependent variable $=$

\begin{tabular}{|c|c|c|c|}
\hline & Fdirector $_{\text {it }}$ & Fmanager $_{i t}$ & Femployee $_{\mathrm{it}}$ \\
\hline \multirow[t]{2}{*}{$\mathrm{PRP}_{\text {it }}$} & $-0.432 * *$ & -1.154 & -4.861 \\
\hline & {$[-2.153]$} & {$[-1.239]$} & {$[-0.585]$} \\
\hline \multirow[t]{2}{*}{ PRPAge $_{i t}$} & 0.055 & 1.525 & $13.200 *$ \\
\hline & [1.057] & [0.948] & [1.803] \\
\hline \multirow[t]{2}{*}{ Flex $_{i t}$} & 0.152 & 0.437 & $29.178^{* *}$ \\
\hline & {$[0.657]$} & {$[0.227]$} & [2.175] \\
\hline \multirow[t]{2}{*}{ FlexAge $_{\text {it }}$} & 0.023 & 0.289 & -2.116 \\
\hline & [0.412] & [0.659] & {$[-0.503]$} \\
\hline \multirow[t]{2}{*}{ Rhours $_{\text {it }}$} & -0.028 & 1.794 & 5.847 \\
\hline & {$[-0.159]$} & [0.944] & [0.379] \\
\hline \multirow[t]{2}{*}{ RhoursAge $_{\text {it }}$} & 0.044 & 0.223 & -0.609 \\
\hline & [0.781] & [0.661] & {$[-0.209]$} \\
\hline \multirow[t]{2}{*}{ Daycare $_{i t}$} & 0.079 & 4.192 & -9.225 \\
\hline & {$[0.223]$} & {$[0.922]$} & {$[-0.325]$} \\
\hline \multirow[t]{2}{*}{ DaycareAge $_{\mathrm{it}}$} & $0.586^{* *}$ & 2.766 & 3.187 \\
\hline & [1.990] & {$[1.530]$} & [0.427] \\
\hline \multirow[t]{2}{*}{ Labor $_{i t}$} & -0.001 & $-0.006^{*}$ & $0.056^{* * *}$ \\
\hline & {$[-1.652]$} & {$[-1.848]$} & [4.322] \\
\hline \multirow[t]{2}{*}{ Pforeigncap $_{\text {it }}$} & 0.148 & -3.612 & $273.020 * *$ \\
\hline & {$[0.130]$} & {$[-0.368]$} & [2.180] \\
\hline \multirow[t]{2}{*}{$\mathrm{ROA}_{\mathrm{it}}$} & 3.211 & 8.650 & 19.579 \\
\hline & [1.188] & {$[0.855]$} & [0.108] \\
\hline \multirow[t]{2}{*}{ Director $_{i t}$} & $0.007 * * *$ & & \\
\hline & [5.896] & & \\
\hline \multirow[t]{2}{*}{ Manager $_{\text {it }}$} & & $0.050 * * *$ & \\
\hline & & [9.512] & \\
\hline $\mathrm{R}^{2}$ & 0.360 & 0.848 & 0.255 \\
\hline $\mathrm{N}$ & 610 & 617 & 684 \\
\hline
\end{tabular}

Data: the Intangible Assets Interview Survey in Japan conducted by the RIETI; CSR Data compiled by Toyo Keizai; and Corporate Proxy Statement Data compiled by Development Bank of Japan.

Notes: All models include firm-fixed effects and time effects. Absolute values of $t$ statistics based on cluster-robust standard errors are in parentheses.

Significance level: $* * * 1$ percent $* * 5$ percent $* 10$ percent 
Table 4 Fixed Effect Estimates on the Effect on Gender Equality of PRP:

Firms with MBO vs. without MBO

Dependent variable $=$

\begin{tabular}{|c|c|c|c|}
\hline & Fdirector ${ }_{i t}$ & Fmanager $_{i t}$ & Femployee $_{i t}$ \\
\hline \multirow[t]{2}{*}{$\mathrm{PRP}_{\text {it }}$} & $-1.029 * *$ & -2.918 & -18.369 \\
\hline & {$[-2.416]$} & {$[-1.065]$} & {$[-1.001]$} \\
\hline \multirow[t]{2}{*}{$\mathrm{PRP}_{\mathrm{it}}{ }^{*} \mathrm{MBO}_{\mathrm{i}}$} & $1.062^{* *}$ & 3.133 & 21.849 \\
\hline & [2.108] & {$[0.758]$} & [0.971] \\
\hline \multirow[t]{2}{*}{ PRPAge $_{i t}$} & 0.146 & 1.322 & $13.778^{*}$ \\
\hline & [1.580] & {$[0.792]$} & [1.948] \\
\hline \multirow[t]{2}{*}{$\mathrm{PRPAge}_{i \mathrm{it}}{ }^{*} \mathrm{MBO}_{\mathrm{i}}$} & -0.169 & 0.372 & -1.24 \\
\hline & {$[-1.342]$} & {$[0.463]$} & {$[-0.304]$} \\
\hline \multirow[t]{2}{*}{ Flex $_{\text {it }}$} & 0.118 & 0.396 & $28.065^{* *}$ \\
\hline & {$[0.572]$} & [0.203] & [2.071] \\
\hline \multirow[t]{2}{*}{ FlexAge $_{i t}$} & 0.013 & 0.305 & -2.19 \\
\hline & [0.219] & [0.657] & {$[-0.522]$} \\
\hline \multirow[t]{2}{*}{ Rhours $_{\text {it }}$} & 0.03 & 2.049 & 7.344 \\
\hline & {$[0.175]$} & [1.110] & [0.459] \\
\hline \multirow[t]{2}{*}{ RhoursAge $_{\text {it }}$} & 0.103 & 0.131 & -0.042 \\
\hline & [1.232] & {$[0.313]$} & {$[-0.013]$} \\
\hline \multirow[t]{2}{*}{ Daycare $_{i t}$} & -0.07 & 4.544 & -10.444 \\
\hline & {$[-0.179]$} & [0.971] & {$[-0.382]$} \\
\hline \multirow[t]{2}{*}{ DaycareAge $_{i t}$} & $0.561^{* *}$ & 2.799 & 2.963 \\
\hline & [2.023] & [1.514] & [0.401] \\
\hline \multirow{2}{*}{ Labor $_{\text {it }}$} & $-0.001 *$ & $-0.006^{*}$ & $0.056 * * *$ \\
\hline & {$[-1.694]$} & {$[-1.838]$} & [4.329] \\
\hline \multirow[t]{2}{*}{ Pforeigncap $_{\text {it }}$} & 0.106 & -3.883 & $272.635 * *$ \\
\hline & {$[0.092]$} & {$[-0.389]$} & [2.173] \\
\hline \multirow[t]{2}{*}{$\mathrm{ROA}_{\text {it }}$} & 3.015 & 8.762 & 18.221 \\
\hline & [1.151] & {$[0.868]$} & [0.101] \\
\hline \multirow[t]{2}{*}{ Director $_{i t}$} & $0.007 * * *$ & & \\
\hline & [5.935] & & \\
\hline \multirow[t]{2}{*}{ Manager $_{i t}$} & & $0.049 * * *$ & \\
\hline & & [9.891] & \\
\hline $\mathrm{R}^{2}$ & 0.369 & 0.849 & 0.256 \\
\hline $\mathrm{N}$ & 610 & 617 & 684 \\
\hline
\end{tabular}

Data: the Intangible Assets Interview Survey in Japan conducted by the RIETI; CSR Data compiled by Toyo Keizai; and Corporate Proxy Statement Data compiled by Development Bank of Japan.

Notes: All models include firm-fixed effects and time effects. Absolute values of $t$ statistics based on cluster-robust standard errors are in parentheses.

Significance level: $* * * 1$ percent $* * 5$ percent $* 10$ percent 
Table 5 Fixed Effect Estimates on the Effect on Gender Equality of PRP:

Firms with INF vs. without INF

Dependent variable $=$

\begin{tabular}{|c|c|c|c|}
\hline & Fdirector ${ }_{i t}$ & Fmanager $_{i t}$ & Femployee $_{\mathrm{it}}$ \\
\hline \multirow[t]{2}{*}{$\mathrm{PRP}_{\text {it }}$} & $-0.570 * * *$ & $-5.012 *$ & $-44.731 * *$ \\
\hline & {$[-2.941]$} & {$[-1.801]$} & {$[-2.325]$} \\
\hline \multirow[t]{2}{*}{$\mathrm{PRP}_{\mathrm{it}}{ }^{*} \mathrm{INF}_{\mathrm{i}}$} & 0.165 & 6.439 & $58.105 * *$ \\
\hline & {$[0.463]$} & {$[1.575]$} & {$[2.217]$} \\
\hline \multirow[t]{2}{*}{ PRPAge $_{i t}$} & 0.061 & 1.647 & $17.763 * *$ \\
\hline & [1.181] & {$[1.048]$} & {$[2.105]$} \\
\hline \multirow[t]{2}{*}{ PRPAge $_{i t}{ }^{*} I_{N F}$} & 0.057 & 0.378 & -6.063 \\
\hline & {$[0.745]$} & {$[0.676]$} & {$[-1.219]$} \\
\hline \multirow[t]{2}{*}{ Flex $_{i t}$} & 0.025 & -0.39 & $34.147 * *$ \\
\hline & {$[0.096]$} & {$[-0.207]$} & {$[2.138]$} \\
\hline \multirow[t]{2}{*}{ FlexAge $_{i t}$} & 0.002 & 0.167 & -4.234 \\
\hline & {$[0.035]$} & {$[0.391]$} & {$[-0.813]$} \\
\hline \multirow[t]{2}{*}{ Rhours $_{\text {it }}$} & 0.014 & 2.041 & 12.96 \\
\hline & {$[0.071]$} & [0.977] & {$[0.758]$} \\
\hline \multirow[t]{2}{*}{ RhoursAge $_{i t}$} & 0.047 & 0.179 & 1.948 \\
\hline & [0.809] & {$[0.583]$} & {$[0.589]$} \\
\hline \multirow[t]{2}{*}{ Daycare $_{i t}$} & -0.162 & 5.162 & -6.107 \\
\hline & {$[-0.466]$} & {$[0.977]$} & {$[-0.192]$} \\
\hline \multirow[t]{2}{*}{ DaycareAge $\mathrm{it}_{\mathrm{it}}$} & $0.573^{* *}$ & 2.576 & 5.185 \\
\hline & {$[2.008]$} & {$[1.503]$} & {$[0.639]$} \\
\hline \multirow[t]{2}{*}{ Labor $_{i t}$} & -0.001 & $-0.006^{*}$ & $0.056 * * *$ \\
\hline & {$[-1.632]$} & {$[-1.869]$} & {$[4.259]$} \\
\hline \multirow[t]{2}{*}{ Pforeigncap $_{\text {it }}$} & -0.501 & 1.211 & $298.065 * *$ \\
\hline & {$[-0.383]$} & {$[0.122]$} & {$[2.015]$} \\
\hline \multirow[t]{2}{*}{$\mathrm{ROA}_{\mathrm{it}}$} & 3.206 & 8.522 & 20.918 \\
\hline & {$[1.056]$} & {$[0.748]$} & {$[0.094]$} \\
\hline \multirow[t]{2}{*}{ Director $_{i t}$} & $0.007 * * *$ & & \\
\hline & [5.914] & & \\
\hline \multirow[t]{2}{*}{ Manager $_{i t}$} & & $0.050 * * *$ & \\
\hline & & [9.556] & \\
\hline $\mathrm{R}^{2}$ & 0.367 & 0.853 & 0.267 \\
\hline $\mathrm{N}$ & 545 & 552 & 601 \\
\hline
\end{tabular}

Data: the Intangible Assets Interview Survey in Japan conducted by the RIETI; CSR Data compiled by Toyo Keizai; and Corporate Proxy Statement Data compiled by Development Bank of Japan.

Notes: All models include firm-fixed effects and time effects. Absolute values of $\mathrm{t}$ statistics based on cluster-robust standard errors are in parentheses.

Significance level: $* * * 1$ percent $* * 5$ percent $* 10$ percent 
Table 6 Fixed Effect Estimates on the Effect on Gender Equality of PRP:

Firms with TRAIN vs. without TRAIN

Dependent variable $=$

\begin{tabular}{|c|c|c|c|}
\hline & Fdirector $_{i t}$ & Fmanager $_{\text {it }}$ & Femployee $_{\text {it }}$ \\
\hline \multirow[t]{2}{*}{$\mathrm{PRP}_{\text {it }}$} & $-0.390^{*}$ & $-3.335 * *$ & -12.314 \\
\hline & {$[-1.770]$} & {$[-2.018]$} & {$[-1.537]$} \\
\hline \multirow[t]{2}{*}{ PRP $_{\text {it }} *$ TRAIN $_{\mathrm{i}}$} & 0.262 & 6.27 & 15.454 \\
\hline & {$[0.546]$} & {$[1.654]$} & {$[0.706]$} \\
\hline \multirow[t]{2}{*}{ PRPAge $_{i t}$} & 0.103 & 1.728 & $13.151 *$ \\
\hline & {$[1.511]$} & [1.098] & [1.869] \\
\hline \multirow[t]{2}{*}{ PRPAge $_{i t} *$ TRAIN $_{\mathrm{i}}$} & -0.195 & -0.597 & 0.841 \\
\hline & {$[-1.215]$} & {$[-0.564]$} & [0.146] \\
\hline \multirow[t]{2}{*}{ Flex $_{i t}$} & -0.004 & 0.511 & $31.379 * *$ \\
\hline & {$[-0.016]$} & {$[0.242]$} & [2.425] \\
\hline \multirow[t]{2}{*}{ FlexAge $_{i t}$} & 0.032 & 0.263 & -2.325 \\
\hline & {$[0.501]$} & {$[0.541]$} & {$[-0.532]$} \\
\hline \multirow[t]{2}{*}{ Rhours $_{\text {it }}$} & 0.027 & 2.172 & 6.046 \\
\hline & {$[0.131]$} & [1.175] & [0.409] \\
\hline \multirow[t]{2}{*}{ RhoursAge $_{\text {it }}$} & 0.053 & 0.287 & -0.595 \\
\hline & {$[0.876]$} & {$[0.865]$} & {$[-0.208]$} \\
\hline \multirow[t]{2}{*}{ Daycare $_{i t}$} & 0.042 & 4.032 & -8.897 \\
\hline & [0.114] & {$[0.920]$} & [-0.313] \\
\hline \multirow[t]{2}{*}{ DaycareAge $\mathrm{it}_{\mathrm{it}}$} & $0.619^{* *}$ & 2.915 & 3.108 \\
\hline & {$[1.988]$} & {$[1.510]$} & [0.397] \\
\hline \multirow[t]{2}{*}{ Labor $_{\text {it }}$} & $-0.001^{*}$ & $-0.006^{*}$ & $0.056^{* * *}$ \\
\hline & {$[-1.717]$} & {$[-1.848]$} & [4.307] \\
\hline \multirow[t]{2}{*}{ Pforeigncap $_{\text {it }}$} & 0.637 & -2.77 & $269.841 * *$ \\
\hline & {$[0.604]$} & {$[-0.294]$} & [2.181] \\
\hline \multirow[t]{2}{*}{$\mathrm{ROA}_{\mathrm{it}}$} & 3.212 & 8.304 & 16.885 \\
\hline & {$[1.185]$} & {$[0.804]$} & [0.093] \\
\hline \multirow[t]{2}{*}{ Director $_{\text {it }}$} & $0.007 * * *$ & & \\
\hline & [5.973] & & \\
\hline \multirow[t]{2}{*}{ Manager $_{\text {it }}$} & & $0.050 * * *$ & \\
\hline & & [9.338] & \\
\hline $\mathrm{R}^{2}$ & 0.37 & 0.849 & 0.256 \\
\hline $\mathrm{N}$ & 609 & 616 & 683 \\
\hline
\end{tabular}

Data: the Intangible Assets Interview Survey in Japan conducted by the RIETI; CSR Data compiled by Toyo Keizai; and Corporate Proxy Statement Data compiled by Development Bank of Japan.

Notes: All models include firm-fixed effects and time effects. Absolute values of $t$ statistics based on cluster-robust standard errors are in parentheses.

Significance level: $* * * 1$ percent $* * 5$ percent $* 10$ percent 